\title{
Desterro: A Monastery Turned Hospital, Now Converted into a Mixed-Use Hub in Lisbon
}

\author{
By Clara Moura Soares ${ }^{*}$, Maria João Neto ${ }^{ \pm}$, Ana Mehnert Pascoal ${ }^{*} \&$ \\ João Alves da Cunha ${ }^{+}$
}

This paper aims to analyse the conversion of the former Desterro Hospital, in Lisbon, the capital of Portugal, both throughout its history and regarding its recent transformation into an innovative project with touristic and cultural purposes. Dating back to 1591, the then Desterro Monastery was transformed into a hospital in 1848, after the extinction of religious orders in Portugal. It kept these hospital functions until 2007, when the Portuguese state decided to close it and to sell the building. The project of comprehensive rehabilitation of the former monastery intended to create a new point of interest in the city of Lisbon, a mix-used building for both locals and foreigners. The restoration project conforms to the historic building, adapting it to present-day requirements. This raises questions on the preservation and identity, also taking into consideration key aspects in terms of sustainability. This paper intends to analyse this case study as an example of maintenance and restoration of a historic building which served various purposes related to religion and healthcare, and which is now starting a "new life", while evaluating such project within the scope of sustainable tourism.

Keywords: monastery, hospital, heritage restoration, mixed-use rehabilitation project, sustainable tourism

\section{Introduction}

Heritage sites and listed buildings have been at the centre of discussions concerning sustainable tourism, particularly regarding their management and conservation as monuments within the current landscape of tourism massification (Mowforth and Munt 1998, Nasser 2003, Rypkema and Cheong 2011, Hall et al. 2016, Gholitabar et al. 2018, Gholitabar and Costa 2018). However, these historic buildings can have other primary functions, while remaining relevant for touristic activities.

This paper intends to address the issue of the refurbishment and repurposing of heritage buildings as it relates to sustainable tourism, with a focus on historic medical buildings. Nevertheless, this particular topic is not commonly dealt with in the analyses of the interactions between built heritage, conservation, and sustainable tourism, both in Portugal and abroad. Within this topic, the researched

\footnotetext{
*Assistant Professor, ARTIS - Institute of Art History, School of Arts and Humanities, University of Lisbon, Portugal.

${ }^{ \pm}$Associate Professor, ARTIS - Institute of Art History, School of Arts and Humanities, University of Lisbon, Portugal.

${ }^{\ddagger}$ ARTIS - Institute of Art History, School of Arts and Humanities, University of Lisbon, Portugal.

${ }^{+}$Center for Studies in Religious History, Portuguese Catholic University, Portugal.
} 
subject will be the conversion of the former Desterro Hospital, located in the old part of the city of Lisbon (in a place called Colina de Santana ${ }^{1}$ ) (Figures 1 and 2). In addition to the history of the building, there will also be an account of the recent proposal that envisions its transformation into an innovative project titled Open Experimental Centre for the World, which includes touristic and cultural purposes. It is, undoubtedly, an interesting case study that highlights the importance of interdisciplinarity and the involvement of several stakeholders throughout the process, such as architects and urban planners, geographers, heritage specialists, doctors, politicians, the private sector, and also the local population.

Figure 1. Mário Novais, Panoramic Photograph of Lisbon Taken from the Nossa Senhora do Monte Square Overlooking the Desterro Hospital Square and Campo de Santana, 1973. PT-AMLSB-CMLSBAH-PCSP-004-MNV-001713. () Lisbon Municipal Photographic Archive

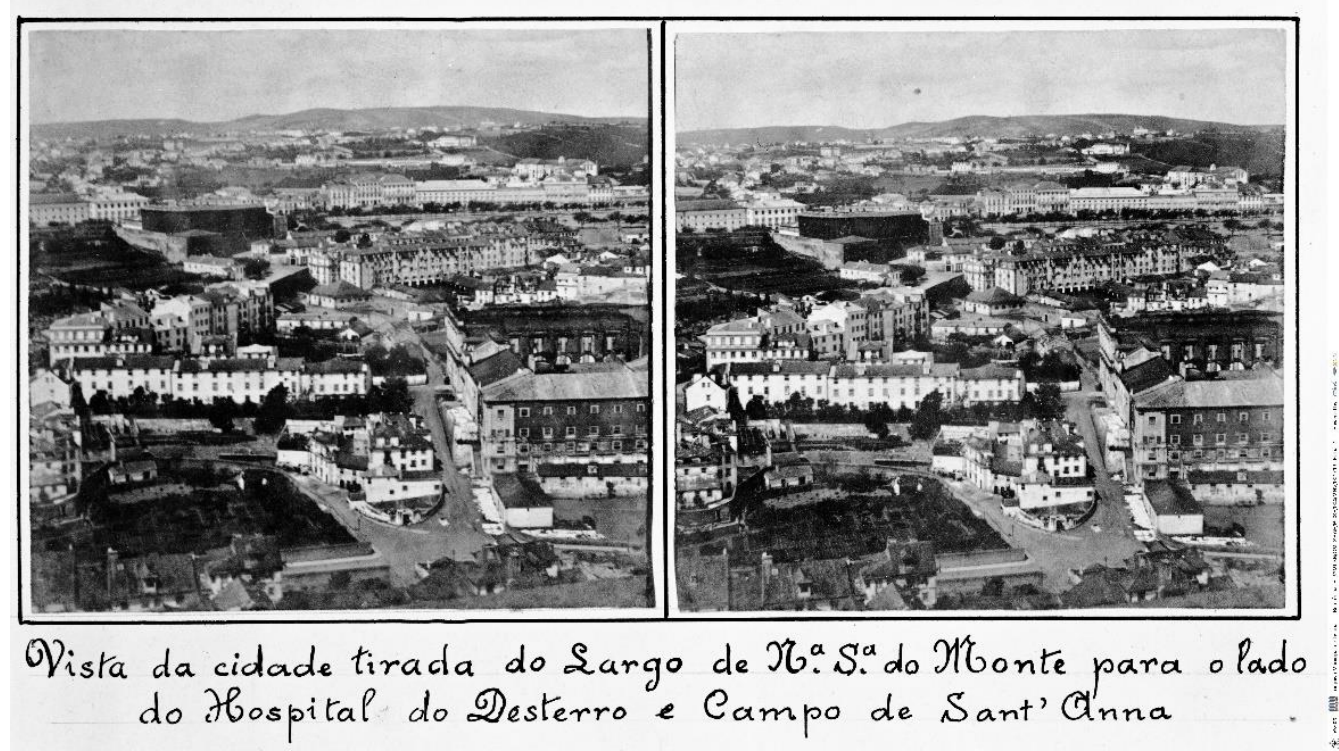

The Desterro edifice, constructed at the end of the $16^{\text {th }}$ century as a monastery of the Cistercian order, carries within its walls various centuries of history, consequence of multiple occupations and repurposes that tended to dilute the architectural coherence of the old monastery.

Thus, Desterro constitutes an emblematic case study affected by the ideological, political and economical circumstances in Portugal, especially over the last two centuries, following the extinction of religious orders in 1834. Thereat the Portuguese Government nationalised the properties of the religious orders and employed the countless large monasteries and convents to house various public services. Such was also the fate of the Desterro Monastery, turned into Desterro

\footnotetext{
${ }^{1}$ One of Lisbon's seven hills, located in the historic centre (spreading through about 183 hectares). Its urban renewal determined the closing of a number of hospitals located within that area (São José Hospital; Santo António dos Capuchos Hospital; Santa Marta Hospital; Desterro Hospital; and Miguel Bombarda Hospital), which occupied former convents, in order to replace them with a new hospital to be built in the eastern part of the city.
} 
Hospital in 1848. Despite the many criticisms expressed throughout the years regarding the inadequacy of the building to serve as a hospital, the situation remained until 2007 due to a lack of alternative solutions.

Figure 2. Eduardo Portugal, Desterro Hospital, Panoramic Photograph Taken from Rua das Olarias Overlooking Avenida Almirante Reis and Rua Nova do Desterro, 1944 PT-AMLSB-POR-010582. CLisbon Municipal Photographic Archive

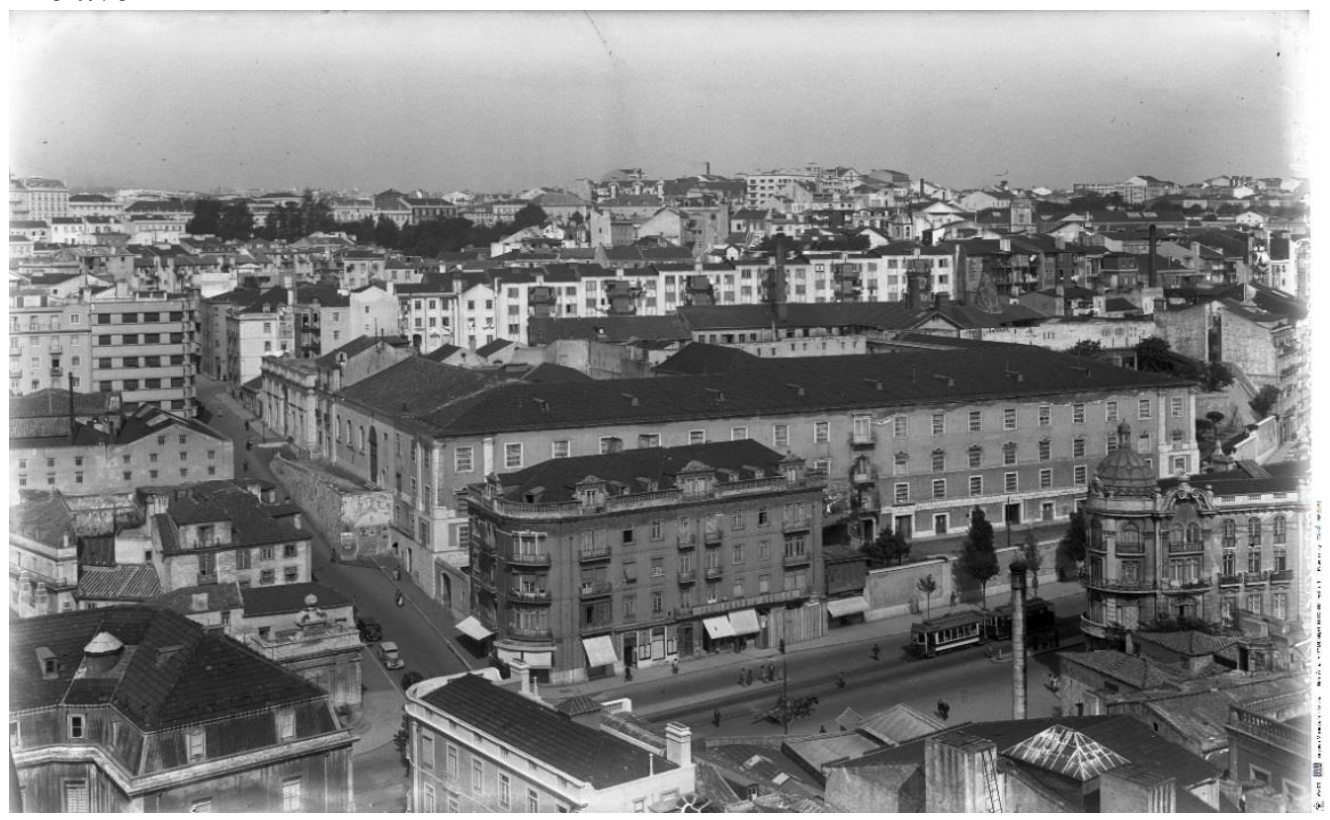

There have been many studies of the Desterro historic building (Pilão and Tacão 2013, Mora 2011, Branco 2008, 2011, 2013, 2014, Bastos and Ramalho 2017). Focusing as much on its architectural aspects as on the several lives of the building - which was a convent and a hospital, but also a military quarter and an orphanage-, each study emphasises certain time periods, individuals or functions, depending on its objectives.

Because memory must not be selective, the successive occupations of this historic building must be acknowledged and remembered, and their signs respected. The work was developed through a systematic archival researchwhich revealed important new information on the history of the building, crucial for its understanding - , to which we added an attentive analysis of the remaining structures (fieldwork), and interviews with the architect responsible for the project of the last intervention in the historic building, we address: the ways this architectural compound was perceived and understood throughout times; how it changed and adapted to its new functions; the role it played within the city dynamics, responding to the most recent tourism-related challenges; and what benefits and risks can tourism bring to this historic building. There has been ample debate on this last topic, regarding the appreciation of the historical heritage of Desterro, the rise in tourism, and real estate speculation. It is nevertheless crucial to address it as it relates to the issue of the conversion of hospitals into hotels, contributing to the debate on this particular type of contemporary use of historic 
buildings (Sousa 2013) —one not often addressed by both Portuguese and foreign authors.

\section{A Former Monastery Converted into a Hospital}

The Real Mosteiro de Nossa Senhora do Desterro, or Desterro Monastery, as it is more frequently called, is an architectural compound originally belonging to the male Cistercian order, built under king Philip I, after the license granted by Pope Clement VIII in 1586.

Its construction began five years later, in 1591, led by architect Baltazar Álvares (Branco 2013, Matos and Branco 2014) who, influenced by the work of Italian Sebastiano Serlio, designed the building in a mannerist style (Figures 3 and 4). In the following reigns, the further expansion of the monastery with the church still under construction would incorporate baroque features into the building.

Figure 3. Convento do Desterro (Hoje, Hospital do Desterro), onde, em Tempos, Esteve Instalada a Casa Pia de Lisboa (Desterro Monastery (Presently Desterro Hospital), where Casa Pia de Lisboa was Once Housed), 1930. PT-TT-EPJS-SF001-001-0017-0859E. (C) ANTT

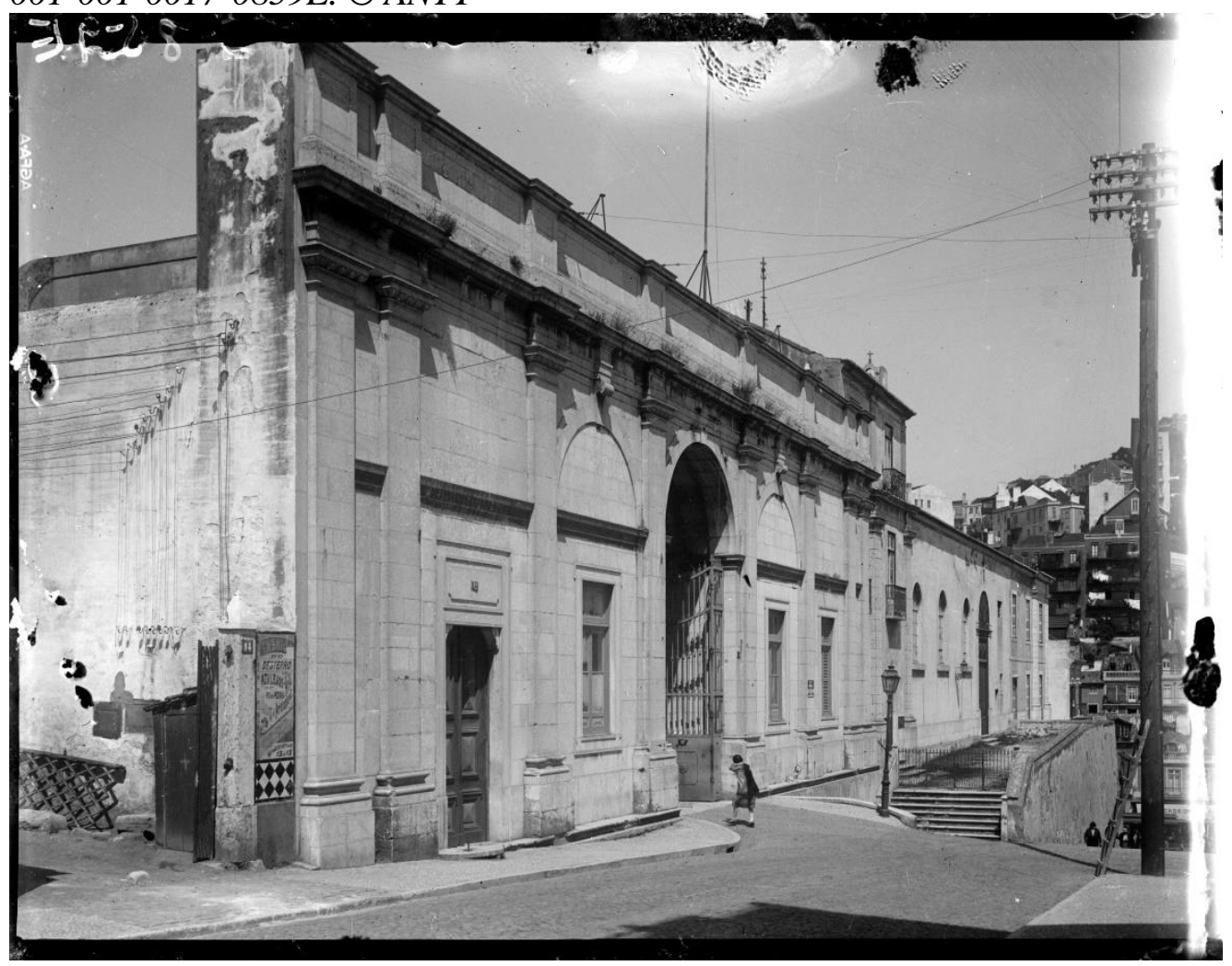


Figure 4. Eduardo Portugal, Desterro Hospital, 1944. PT-AMLSB-POR-060210. (C) Lisbon Municipal Photographic Archive

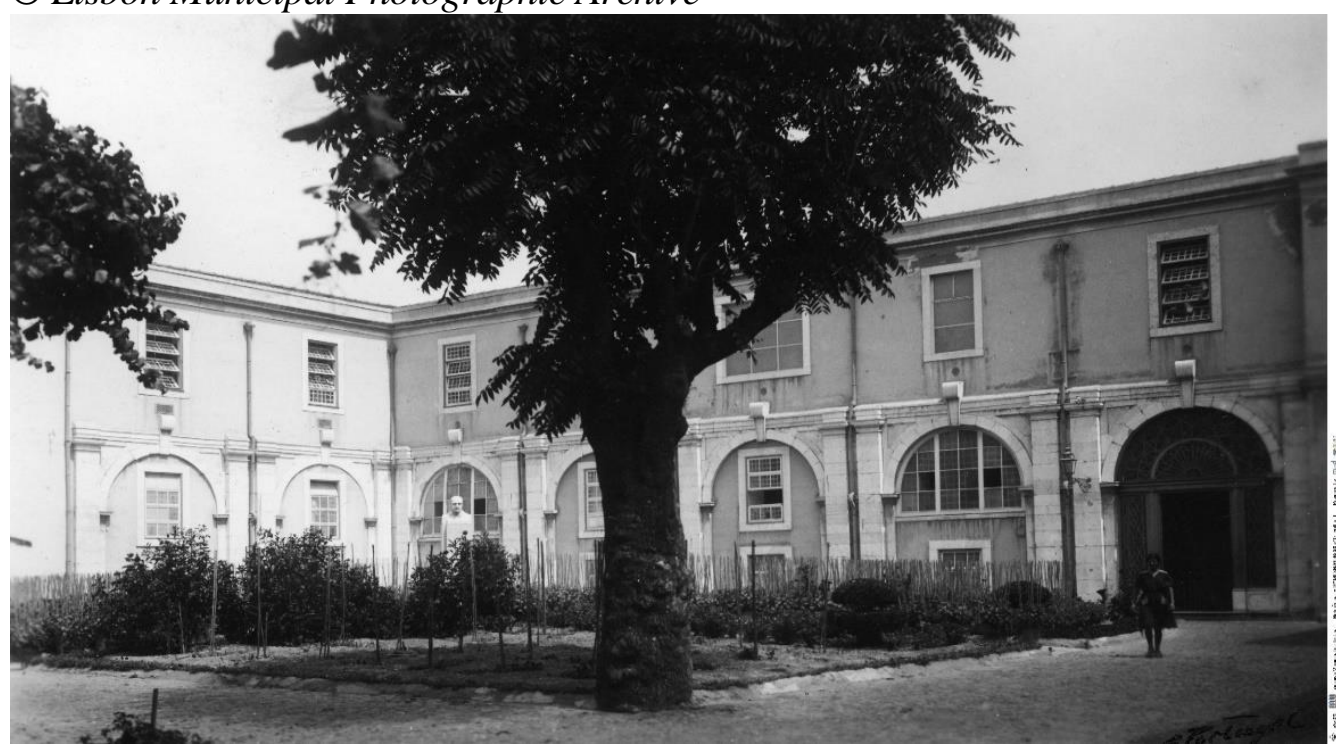

However, the project remained unfinished, with the interruption of the construction work in the beginning of the $18^{\text {th }}$ century - when the church, though in an advanced stage, was yet to be concluded, as was the case with other structures of the monastery (Projeto Lx Conventos - Mosteiro de Nossa Senhora do Desterro).

During its pre-nationalisation existence, the monumental building — with a constructed area of about 8,400 square meters and located in a central part of the city_ took on many functions (see Table 1).

Table 1. Different Functions of the Desterro Building ${ }^{2}$

\begin{tabular}{|l|c|}
\hline 1750 & $\begin{array}{c}\text { Temporarily houses the patients of the Hospital Real de Todos os } \\
\text { Santos, who had to be transferred due to a fire. }\end{array}$ \\
\hline $1796-1806$ & Some services of the Navy Hospital. \\
\hline $1804-1858$ & Quarter of several military companies (Lima 2014, 249). \\
\hline $1811-1833$ & Casa Pia de Lisboa orphanage (1811-1833). \\
\hline 1835 & Courtroom. \\
\hline 1839 & Primary Education School, operating in some adjacent buildings. \\
\hline From 1848 on & Hospital annexed to the São José Hospital. \\
\hline 1849 & Lodging for families in need. \\
\hline 1853 & Some facilities of the Colégio Militar (Military School). \\
\hline 1860 & Aula Régia ${ }^{3}$. \\
\hline
\end{tabular}

\footnotetext{
${ }^{2}$ Summary table systematized by the authors according to the archive documentation.
} 
From 1848 onwards, the Desterro building was annexed to Hospital de São José $^{4}$, specifically dedicated to combating the cholera epidemic that ravaged the city (Cabral 1915, 237). In this context, Desterro would take on the hospital functions it had essayed in 1750, and which would extend for over one and a half century (Figure 5). During that period, it was a crucial hospital in combating yellow fever (1857), syphilis, and other venereal diseases (1862); and it specialised in dermatology (1897) and urology (1918), with some of the most notable clinicians of the country having practised there (Mora 2011).

Figure 5. Homenagem do Pessoal do Hospital do Desterro ao Respetivo Fiscal, António Lúcio dos Santos (Claustro) (Homage Paid by the Desterro Hospital Staff to the Hospital Supervisor, António Lúcio dos Santos (Cloister)), 1930. PT-TTEPJS-SF-001-001-0016-0639E. (C) ANTT

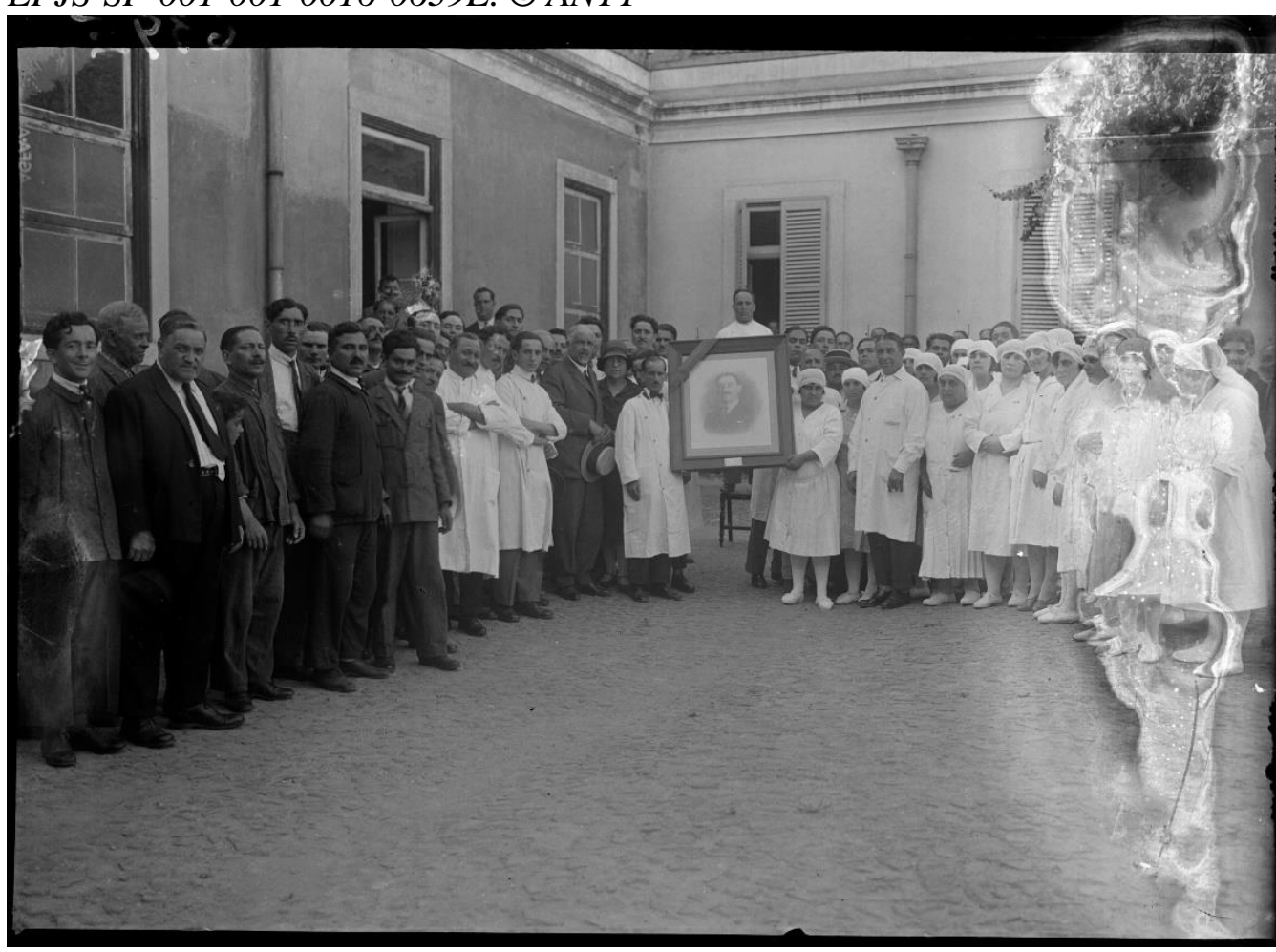

With each new occupation, various adaptations were made to the building, which altered its appearance and increasingly concealed its 15 th-century origins. The conversion of the building into a hospital, in particular, led to the addition of several partition walls and false ceilings in order to create new rooms and organise wards; and also to the construction of new structures annexed to the building, destined to accommodate necessary facilities. Furthermore, the windows of the former monks' dormitory were enlarged, the cloister arches were covered, a second storey was added to the large cloister, the upper parts of the mannerist

${ }^{3}$ First kind of organised public secular education, established in Portugal in the $18^{\text {th }}$ century, free from the influence of the Church and of the Jesuits in particular.

${ }^{4} 1848.11 .29$ - Government ordinance authorising the hospital to keep the building of the deactivated Desterro Monastery. PT/AHM/DIV/3/20/22/48. 
façade that gave access to the former church were suppressed, and its triple archway, as well as the existing niches, were covered.

"Various construction works, improvements, maintenance operations, and repairs" are made on the existing structures (Cabral 1915, 281-285), particularly the enlargement and equipping of the bathing facilities for the disinfection of patients, the expansion of the outpatient consultations area, and the construction of a proper chapel. Following the $1946^{5}$ hospital organisation campaign promoted by the Estado Novo (New State) ${ }^{6}$, more thorough rrefurbishing works are made in the Desterro building. From 1950 onwards, the Direção Geral dos Edifícios e Monumentos Nacionais (General Directorate of National Buildings and Monuments) $\left(\mathrm{DGEMN}^{7}\right)$ services act upon the hospital facilities - repairing roofs, enlarging facilities, installing a resuscitation room and a patient lift, creating treatment rooms, operating theatres and an X-Ray Laboratory ${ }^{8}$-, in order to keep the hospital functional and adapted to current needs.

Prior to that, the construction work was mainly focused on the large support wall of the former monastery. This wall had been erected in the beginning of the $20^{\text {th }}$ century, after the opening of the monastery enclosure wall, when the entrance on the side of Almirante Reis Avenue - a new and structural main artery for the northwards expansion of Lisbon-was built. Following architect Artur Simões da Fonseca's project, a decision is made towards the softening of the visual impact of the wall structure on the public road, which contributes to a better articulation between the building and the avenue, and also allows to enliven the long wall with small commercial establishments.

The successive postponements of the deactivation of Desterro would lead to a threefold problem: the adaptation works were often insufficient to respond to new and demanding functions; various pre-existing architectural and artistic features were repeatedly altered and destroyed; and the opportunity for constructing modern buildings originally conceived to cater to specific hospital needs was suppressed by the repurposing of such older buildings.

These issues, added to the lack of hygiene conditions, often led to the questioning of the existence of the Desterro Hospital throughout the $19^{\text {th }}$ and $20^{\text {th }}$ centuries; a new hospital was even projected to be built in another area of the city (Alto de Santo Amaro), which never materialised (Mora 2011, 42).

Hence, Desterro - and the other hospitals operating in former monasteries in Lisbon-will feed the public debate regarding specific instances of the reorganisation of health services in Portugal, the repurposing of public buildings, and also the management of the government budget. If, in the $19^{\text {th }}$ century, the focus was on political and medical issues - namely the poor hygiene conditions, the lack of ventilation, the excessive humidity, and the shortage of space, beds and nursing equipment-, in most recent years - and due to the intense debate on

\footnotetext{
${ }^{5}$ Decree n. 2011, 02.04.1946. Diário do Governo, n. 70, Series I, 02.04.1946.

${ }^{6}$ Dictatorial political regime that ruled Portugal between 1933 and 1974.

${ }^{7}$ Sate organisation created in 1929 with the role of managing the construction works made on national buildings and monuments.

${ }^{8}$ SIPA-DGPC, Hospital do Desterro, Processo Administrativo; MOP, "Obras Públicas concluídas" e "Melhoramentos" a inaugurar a cada ano no Hospital do Desterro (1950-1970).
} 
Colina de Santana, regarding issues such as real estate expectations and urban renewal-a new topic is introduced, concerning the importance of heritage to the determining of the future of such buildings. The acknowledgement of the past and identity of the place, based on the architectural, historical, scientific, artistic and cultural heritage of Colina de Santana, was crucial in the process that ensued the sale of the hospital buildings in that part of the city, where Desterro is located (ALM 2014).

\section{What Future for the Former Royal Monastery and Hospital?}

As previously mentioned, the former Desterro Monastery and Hospital reached $21^{\text {st }}$ century as an incomplete Cistercian building, significantly marked by the many additions introduced during the time when it served as a hospital. Like many other monasteries and convents converted into hospital settings, the building did not pacifically embrace the often forcefully imposed specific demands of its new role, which were detrimental to pre-existing architectural elements (Branco 2010, 10). Conversely, the hospital never had in the monastery a neutral space adequate to its function. For this reason, the Desterro Hospital became part of a group of buildings in similar circumstances - S. José, Santa Marta, and Capuchos hospitals-, destined to be sold in order to fund the long-awaited future Hospital de Lisboa Oriental (Eastern Lisbon Hospital).

Deactivated in 2007, the building became a property of Parpública, a government-owned company which two years later put the building up for sale for 10.75 million Euros. This number was later reduced to 9.55 million Euros, which nevertheless did not attract any buyers - certainly a direct consequence of the stipulation that mandated the building to be exclusively employed in the continuous care area. After the failure of this operation, the building was bought for 9.24 million Euros by Estamo, a subsidiary of Parpública which manages sateheld real estate, and which drastically changed the strategy in regards to this building.

In 2013, Estamo signed a protocol with the Lisbon City Council and the company Mainside - known for its intervention in LX Factory ${ }^{9}$, in Alcântara - in order to transform the former monastery and hospital into an "experimental space open to the world" (Soares 2013). For the city council, this was a strategic building for the intervention within the Martim Moniz - Praça do Chile axis, since it could established itself - due to its size, location, and relevance - as a fundamental anchor for the regeneration and revitalisation of the whole area, especially in regards to tourism (Figure 6). The goal of the company responsible for the management of the building was to inaugurate it still in that same year, launching a phased intervention to transform the building into a campus of learning with spaces available for cultural events, and also spaces for working, for accommodation, for "planting a vegetable garden, attending a debating club,

\footnotetext{
${ }^{9}$ Abandoned historic industrial compound where, after rehabilitation and improvement works, restaurants, bars, bookshops, art stores, and offices of dozens of companies operating in different fields were established.
} 
having lunch at a community dining hall, or attending classes or workshops, among many other experiences provided by various companies and organisations" (Soares 2013). The goal was, essentially, to replicate the project that had been successfully implemented in Alcântara, creating a space that allowed to diversify the touristic offers in that part of the city, while considering the economic, social and environmental impacts of its activities, based on a model of sustainability which would take into consideration the needs of visitors, of the environment, of local communities, and also of the economic organisations.

Figure 6. Pedro Domingos Arquitetos. Restoration Project for the Former Desterro Monastery/Hospital, Lisbon, 2013-2017

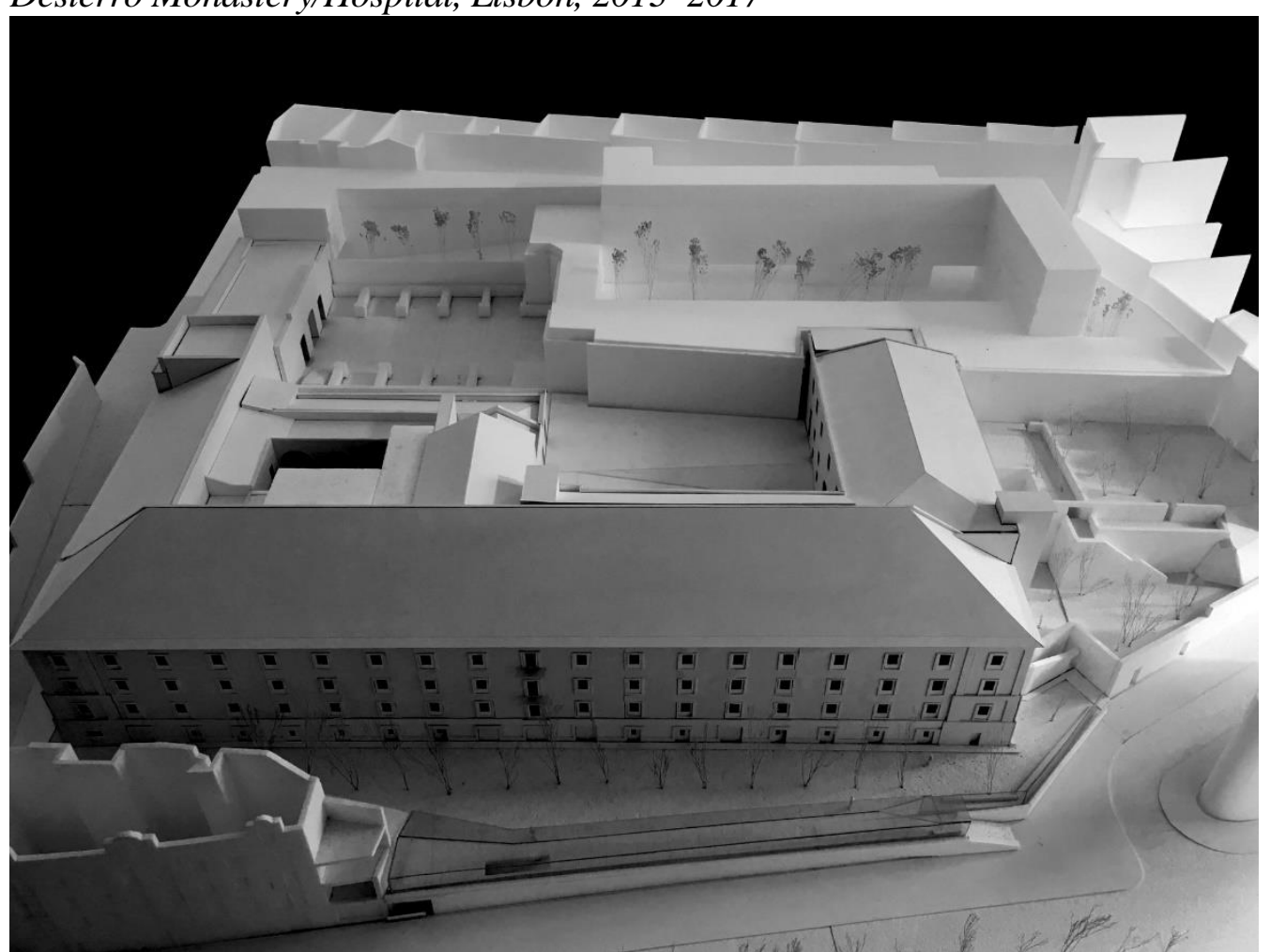

Within this framework, still in 2013, a "set of construction works" took place, "as part of a first phase of interventions that aimed to clear up the area, in addition to the demolition of some elements which were not originally part of the Nossa Senhora do Desterro Monastery, specifically additions of no heritage value dictated by the necessities of the hospital setting" (Soares 2014). Afterwards, the works unpredictably stopped, which marked the beginning of a series of successive delays - on the one hand frustrating, but on the other also beneficial, for they allowed for the ripening of the concept initially proposed (Pincha 2018). The qualification of this project and its better justification were greatly impacted by the multidisciplinary team that was formed in the meantime, composed of architects, archaeologists, and historians. ${ }^{10}$ The work developed by this team was

${ }^{10}$ Project team: Architecture - Pedro Domingos Arquitectos (Pedro Domingos, João Favila,
João Simões, Pedro Gonçalves, Bruno Antão, João Bagorro, Nuno Castro Caldas); Structures - 
so important as to lead to the redefinition of the plan established for the building; the analysis carried out by historians was of particular significance.

In 2014, José Sarmento Matos and Ricardo Lucas Branco presented a historical and patrimonial study of the building, with guidelines for its architectural reintegration aptly supported by the new information uncovered during the clearing and demolishing operations carried out in the previous year. This study was particularly critical of the alterations made during the conversion of the monastery into a hospital, from the mid-19th century until the end of the $20^{\text {th }}$ century. According to José Sarmento de Matos and Ricardo Lucas Branco, these modifications were not the same as the aesthetic additions or remodellings frequent in the history of buildings, to which they add heritage value. "We can indeed declare that such kind of additions are absent from the former Desterro Monastery" (Matos and Branco 2014, 16). Thus, for this historian, "Nothing in the building was replaced by an apt nor dignified architectural element or structure, one that could have been advantageous for the object itself or for its assigned function. On the contrary, one can often notice various alterations, severe obliterations, and strictly functional depreciating additions (many poorly built, as temporary elements), which contributed to the progressive defacement of the building" (Matos and Branco 2014, 22). This also hindered the recognition of its heritage value. For all these reasons, the author argued that the intervention should focus on the architectural features as devised by Baltazar Álvares, pursuing a patrimonial reintegration as close as possible to the notable historic monument as it once was, according to what had been revealed and confirmed by the first intervention procedures.

Adopting this concept as purpose, the architectural project presented in the beginning of 2015 defended, from the start, the resumption of the process of studying and uncovering the monastery site, which had begun in 2013. The alterations made during the hospital period were described as "careless and very dissonant with the architectural identity of the monastery", hence, in order to add value to the building, it was fundamental to rid it "of the spurious annexes and additions of no heritage interest, which have defiled it" (Domingos 2015, 3). It was therefore necessary to proceed with the clearing and demolition operation, as to uncover the noteworthy spaces of the former monastery, which were originally vaster, as well as the stone arched roofs and columns that were concealed within the partitions and fake ceilings built during the hospital period (Figures 7 and 8). However, it is worth mentioning that the intent of the project's authors was not to completely erase the building's most recent history by limiting the intervention to the recovery of the splendor of the original monastery structures. While reopening and clearing the spaces, the marks of the hospital partitions would not be erased; rather, they would remain visible on the walls ${ }^{11}$.

A2P (João Appleton, Pedro Ribeiro, Tomás Nunes da Silva); Infrastructures - ATPI (António Lemos, Dias da Silva); Archaeology - ERA (Miguel Lage, Mafalda Capela, Pedro Braga); History of Art and Urbanism - José Sarmento Matos, Ricardo Lucas Branco.

${ }^{11}$ Information supplied by architect Pedro Domingos in an interview made on 25 July 2019. 
Figure 7. Restoration Project for the Former Desterro Monastery/Hospital, Lisbon, 2013-2017. Demolition Works in the Monks' Dormitory. (C) Pedro Domingos Arquitetos

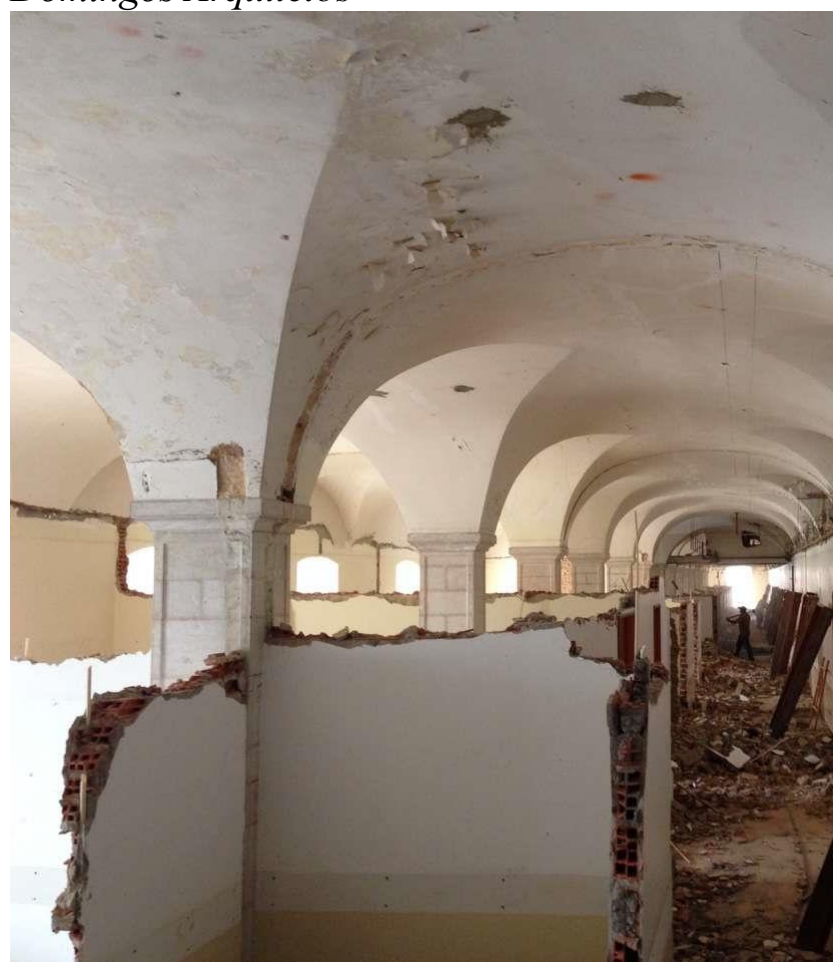

Figure 8. Restoration Project for the Former Desterro Monastery/Hospital, Lisbon, 2013-2017. Demolition Works in the Monks' Dormitory. C Pedro Domingos Arquitetos

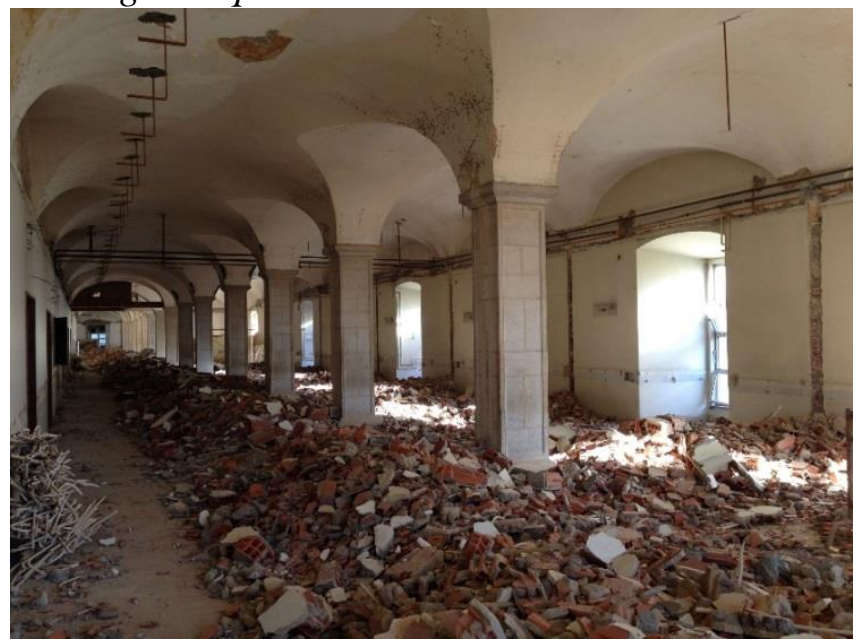

This intervention, which aimed to reveal and clarify the original structure of the former monastery in its entirety, was divided into two phases. The first focused on the large element that spreads along Avenida Almirante Reis, and consisted in a series of demolitions and clearing operations with the purpose of recovering the original spatial organisation and its architectural characteristics. In regards to the 
interior of the building, the project suggested the uncovering of the columns which supported the arched roofs of the eastern and northern wings-which were embedded in more recent walls or in non-structural partitions - in order to reestablish the passage and the two-naves configuration of many of those areas, an aspect fundamental to the reading of the site and to the understanding of its primordial function. As to the façade on the side of Avenida Almirante Reis, the project outlined the restoration of the portholes back to their original form-since most of them had been enlarged with distinct additions of square stone pieces to the frames due to the need for better lighting in the hospital setting (Domingos 2015, 4).

The more complex intervention planned for the two cloisters, which involved the "restoration of their original form, including the reopening of the archways and the reestablishment of passage in its galleries, will be one of the main goals of the restoration of the former monastery" (Domingos 2015, 3), had to be postponed to a second phase (Figures 9 and 10). In regards to the northern cloister, there was also a plan to demolish the large concrete stairs, which had been built on top of the gallery of the former monastery cloister, so as to allow for later archaeological investigations with the purpose of uncovering some of the former structures. This project of creating a permanent archaeological site was extended to the southern cloister and to the church area, in order to allow for some continuity in the study and uncovering of the hitherto concealed structures of the former monastery. For this reason, the demolition of the annexed structures located on top of the former nave of the church was also suggested, as to allow for a future archaeological excavation to reveal the structure of the former church.

Figure 9. Restoration Project for the Former Desterro Monastery/Hospital, Lisbon, 2013-2017. Larger Cloister. (C) Pedro Domingos Arquitetos

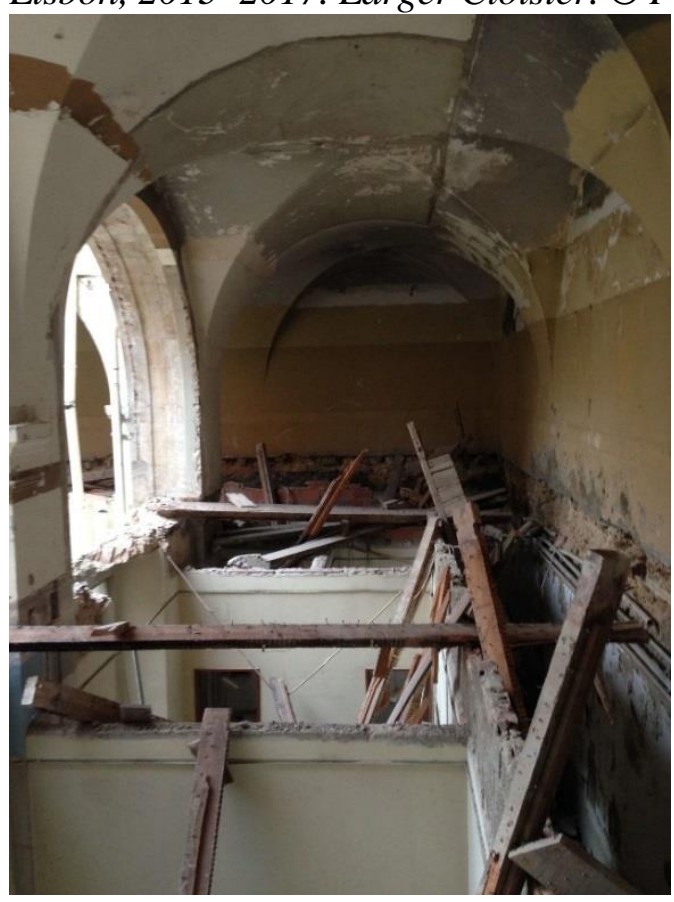


Figure 10. Restoration Project for the Former Desterro Monastery/Hospital, Lisbon, 2013-2017. Larger Cloister. (C) Pedro Domingos Arquitetos

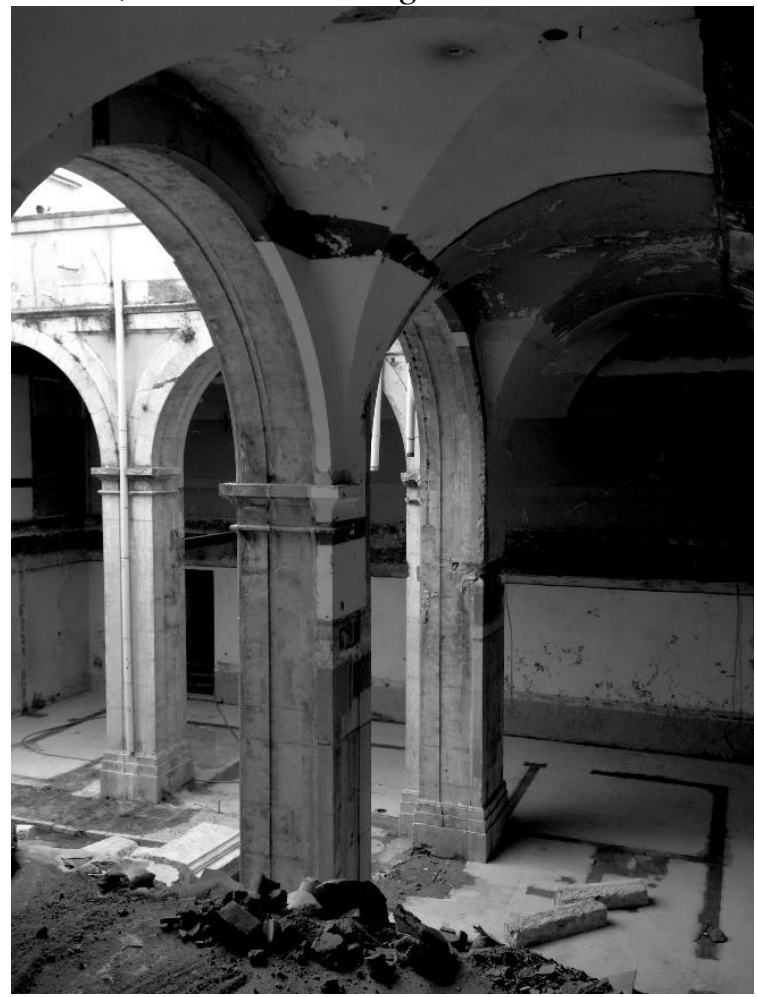

Other than the continuing of the study and uncovering of the concealed structures, and the revelation of the original areas of the monastery, two main features of the architecture project were the opening of the building to the city and the reversibility of the new elements. The former point included the introduction of a new street that enabled the creation of two new entryways to the building. This project determined the full demolition of the four existing commercial establishments on the Avenida Almirante Reis side, and of the ruins of the building connecting the rear front of the Desterro building and the no. 1 of Avenida Almirante Reis, the partial demolition of the wall on the side of Rua Antero de Quental, and the demolition of the former hospital incinerator. This intervention would allow not only to uncover the quoins of the eastern façade - thereby enabling it to be seen as a whole-, but also to create a green area on an external platform at the level of the first floor of the former monastery, directly connected to Rua Antero de Quental, Rua Nova do Desterro and Avenida Almirante Reis.

This new street would take on a dual purpose, as a new public place in the city, and also as a connecting link between the former monastery and the city.

Similarly, the project for the four levels of the eastern part of the edifice sought to promote the desired opening of the building to the city, by occupying it with different purposes, for diverse audiences, and with various opening times. For this reason, it was suggested that each floor should have an independent use, with the possibility of each having its own separate entrance. The first floor would be occupied by restaurants, and would have a direct access to the street. The idea that served as reference was "the kitchen set around the fire, ... a big communal dining 
hall, set around an imposing fireplace, symbolising fire as the main element" (Tomás 2015). For the second floor, a more conventional 20-room hotel was proposed.

In addition to the spacious polyvalent nave, which would be available for cultural — and other - uses, the third floor would house a centre for well-being or for alternative therapies "with naturopathic, acupuncture or ayurvedic consultations and treatments, massages, or wellness and healthy eating workshops, complemented by a revival of bibliotherapy and cinema therapy, in which treatments are accompanied by books and films. The idea is to provide consultations with specialists in traditional Chinese medicine or even conventional medicine, depending on the diagnosis, and to complement the treatment with books or films" (Tomás 2015). This project was inspired by the British medical publication Novel Cure.

The project for the fourth and final floor consisted in a hostel-type accommodation unit, furnished with a modular system of 50 removable wooden capsules. This would constitute one of the most representative examples of the intention of occupying the building with non-intrusive, reversible systems by using structures and facilities easy to disassemble in the future.

It can therefore be concluded that, rather than a conventional restoration, the architectural project envisioned a process of subtraction and stabilisation of the existing structures in order to prepare the spaces for a temporary occupation - one that, upon its ending, could be quickly removed, without leaving any marks, completely freeing the spaces for new purposes ${ }^{12}$. In December 2018, after the announcement of various dates for the opening of the first spaces, the third trimester of 2019 was declared a possible date for "a partial opening, obviously depending on the developments of the space adaptation works" (Pincha 2018). Upon the arrival of the advertised date, one could see, from the new street, that something was changing in the former Desterro Monastery and Hospital. But that was it. As for the rest, the city still awaits the new life of this monument (Figures 11-13).

\footnotetext{
${ }^{12}$ Information supplied by architect Pedro Domingos in an interview made on 25 July 2019.
} 
Figure 11. Desterro Building. Narthex Façade. (CCMS, 07.2020

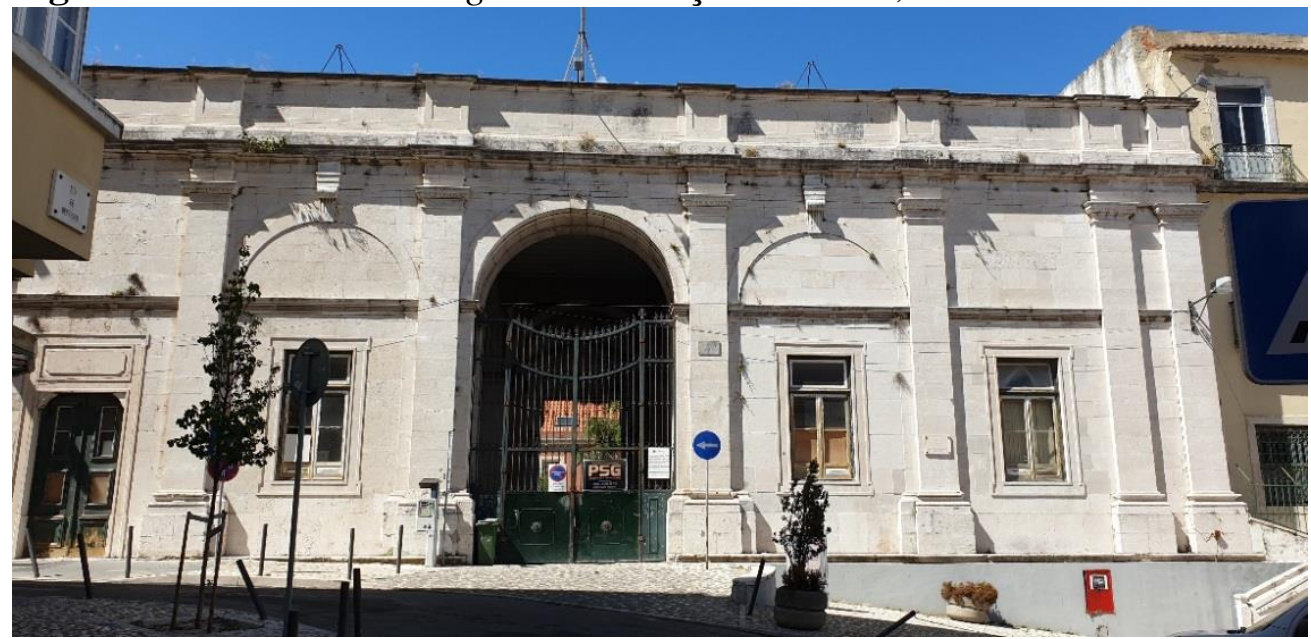

Figure 12. Desterro Building. Partial View of the Narthex Leading to the Church which was Demolished in the $19^{\text {th }}$ Century (C) CMS, 07.2020

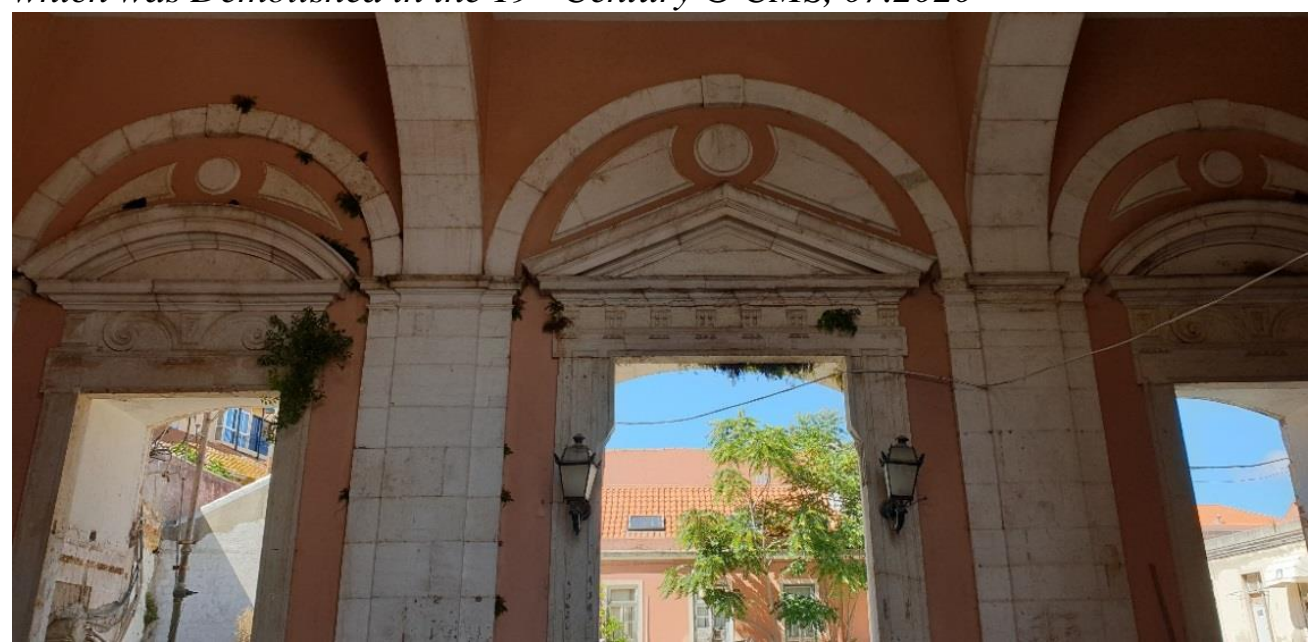

Figure 13. Desterro Building. Partial View of the Lateral Façades. CCMS, 07.2020

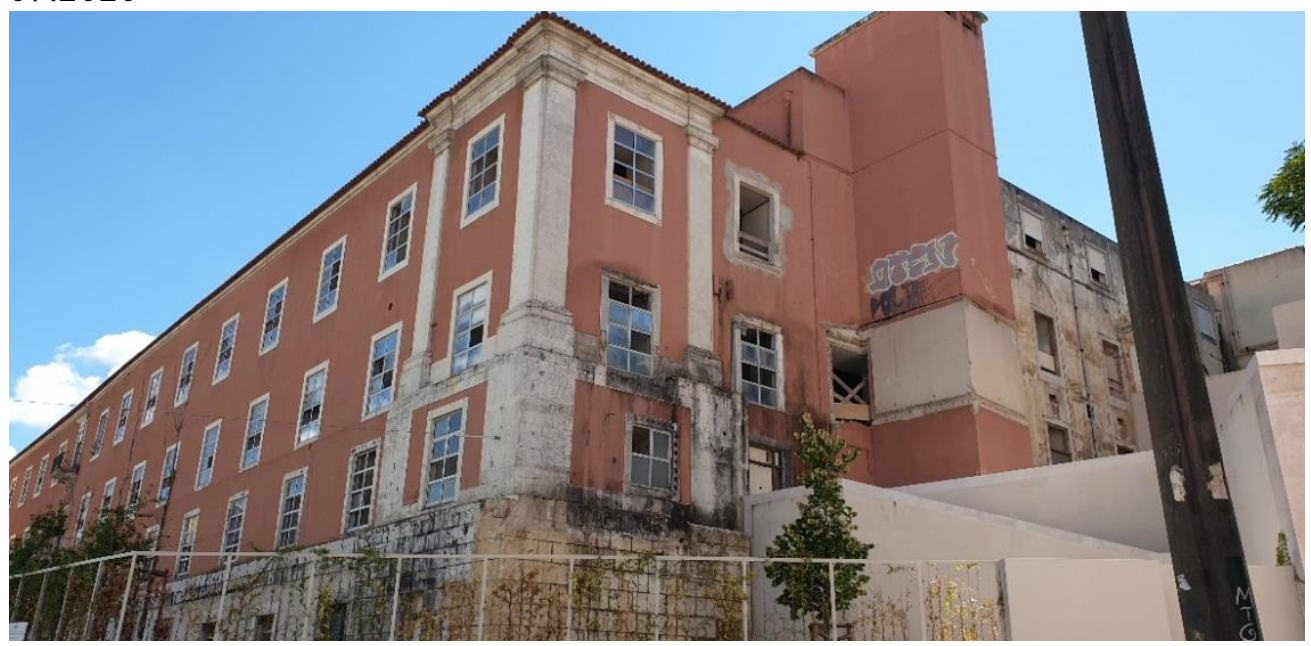




\section{Discussion}

The sale by the Portuguese government of a group of historic hospital buildings in the Colina de Santana-most of them occupying former convents, as was the case with the former Desterro Hospital-provoked an intense public debate involving many institutions and specialists. This process led to the maintenance of hospital functions in most of the buildings, to the postponement of the construction of the new hospital in eastern Lisbon, and to the suspension of the repurposing projects conceived for the hospitals that were already deactivated (as was the case with the Desterro hospital).

The topic of shutting down hospitals is controversial on its own; the controversy is naturally aggravated when the new life of such establishments is associated with tourist accommodation - even when these include spaces dedicated to cultural events, or when clinical services keep being provided in the building, as was the case with Desterro.

Certainly due to such reasons, examples of hospitals converted into hotels do not abound in Portugal nor in any other country. Such project constitutes a considerable challenge involving various participants (Government, private sector, various professionals of architecture, urbanism, medicine, art history, etc., local communities, tourists) and is frequently subject to extensive public debate.

In the Council of Europe Convention on the Value of Cultural Heritage for Society, signed in Faro, in 2005, important aspects such as the "contribution of cultural heritage to society and human development", "environment, heritage and quality of life", "sustainable use of the cultural heritage" and "cultural heritage and economic activity" are reinforced.

In line with these ideas, and taking into account the principles of the Vienna Declaration (2009) under the motto "An Incentive to Heritage in the Period of Economic Recession"13, the Portuguese government implemented in 2009 a national programme to restore classified heritage buildings, involving the private sector in their safeguarding ${ }^{14}$. In 2016, the Programa Revive (Revive Program) ${ }^{15}$ was launched to support private investment in the restoration and repurposing of state-held heritage properties into tourist attractions, turning them into a national economic asset. The buildings made available include former convents, castles, fortresses, and private palaces. In Portugal, as in many other countries where tourism has such a great weight in the Gross Domestic Product (Ismagilova et al. 2015, Papanikos 2020), the official discourse has regarded built heritage as a valuable resource for the country's economic development in association with the tourism sector.

\footnotetext{
${ }^{13}$ The Vienna Declaration, drafted within the framework of the European Forum of Responsible for Heritage (EFRH), calls on all national governments to recognise the fundamental role of heritage in the development and implementation of sustainable economic recovery policies.

${ }^{14}$ Programa de Recuperação do Património Classificado (Classified Heritage Restoration Program). Resolution of the Council of Ministers n. 70/2009. Diário da República, 1st series, n. 162, 21.08.2009 (https://dre.pt/application/file/a/488241).

${ }^{15}$ Programa Revive: presentation (https://revive.turismodeportugal.pt/en).
} 
There is an obvious reciprocal relationship between cultural tourism and historical heritage. Thus, if on the one hand revenue from the growth of heritage tourism can be an effective way of preserving cultural heritage buildings, on the other hand the revitalisation of historic buildings should be seen as an important asset for tourism development. In general terms, their adaptation to the needs of tourism - not always peaceful and sometimes implying a risky relationship (Dris 2016, Nilsson 2018) - is often, from a multi-faceted understanding, the most sustainable option (from an economic, cultural, social and environmental point of view) to assure their preservation for future generations (Langston et al. 2008). However, it is crucial that principles such as those invoked by the Faro convention, mentioned above, are properly respected, withal, contributing to the economic and social development of the neighbourhood (Powter and Ross 2005, Barthel-Bouchier 2013) while ensuring that refurbishments and adaptive reuses of cultural heritage buildings do not irreparably damage the existing historical testimonies and resources (Boudiaf 2019).

Nevertheless, the issue becomes more complex when the heritage sites associated with the tourism industry are former hospitals, even when the project is aligned with sustainable tourism principles - which World Tourism Organisation defines as a practice "that takes full account of its current and future economic, social and environmental impacts, addressing the needs of visitors, the industry, the environment and host communities" 16 .

In Portugal, there are few cases of historic buildings of healthcare facilities employed by the tourism sector. Representative examples include the Hotel Palacete do Mondego, in Penacova, a former tuberculosis preventorium, which opened as a hotel in 2001 (and closed six years later); Pousada de Viseu, in the former Misericórdia Hospital, inaugurated in 2009 as a hotel designed by architect Gonçalo Byrne; Pousada Serra da Estrela, in Covilhã, a former sanatorium which reopened as a hotel in 2014, with a project by awarded architect Eduardo Souto de Moura (recipient of the Pritzker Architecture Prize in 2011); or Vila Galé Collection Braga, a former hospital (S. Marcos Hospital) which was converted into a hotel with a project by Miguel Guedes Arquitetos in 2016-2017 (Pascoal et al. 2020). These projects usually combine funding from official and community sources and from the private sector; the restoration plans are usually designed by a renowned architect, and often have the objective of establishing a luxury hotel.

In the international panorama, there are some particularly challenging cases somehow comparable to Desterro, for their many centuries of history, and for having functioned as convents and hospitals. Such is the case with the Hôtel-Dieu de Lyon (France), a hospital founded in the $12^{\text {th }}$ century by the semi-monastic Pontifices Fratres brotherhood, which reopened as a five-star resort (InterContinental Lyon, Hôtel-Dieu 2019) after being restored with a project by architect Jean-Philippe Nuel in collaboration with Didier Reppelin, chief architect

\footnotetext{
${ }^{16}$ UNWTO. Our focus: sustainable development. https://www.unwto.org/sustainable-development.
} 
of Historic Monuments (Ayers 2019) ${ }^{17}$. This building is located in the Historic Site of Lyon, classified by UNESCO as World Heritage.

Another interesting example can be found in Tel Aviv (Israel). In this case, the British architect John Pawson together with the local historic conservation architect Rami Gill were called upon to restore and convert the School of the Sisterhood of Saint Joseph Convent and an adjacent $19^{\text {th }}$ century former hospital into the stunning Jaffa Hotel (which opened in 2018) ${ }^{18}$.

There are also some cases of deactivated and ruined health facilities converted into spacious and inviting hotels. To mention a few: the St. Columba's Lunatic Asylum in Ireland, transformed into the restful Clarion Hotel Sligo (2005); or the Comwell Kellers Park (Børkop, Denmark), turned into a hotel with Danish flair, set in the beautiful and historic scenery overlooking Vejle Fjord (2008); or the former Buffalo Asylum (Buffalo, New York), converted into the Hotel Henry Urban Resort Conference Center (2017). (Flanagan 2018).

In any of the cases mentioned above, the projects were conceived taking design, memory, consumption, and real estate into consideration, which is often regarded in specialist literature as a sort of "magical solution" for urban restructuring (Safara and Brito-Henriques 2018).

The repurposing of historic buildings for contemporary use, based on its adaptive reuse (Ferreira 2014) became frequent and often desirable, since it solves the issue of abandonment and decay of many historic buildings which no longer fulfilled the roles they were conceived or repurposed for (Palmer et al. 2012). In other words, the attribution of a new role arises as the best warranty for the building's survival, allowing it an active participation in contemporary society. It is nevertheless fundamental to observe a "compatible use", i.e., "a use which respects the cultural significance of a place" and which "involves no, or minimal, impact on cultural significance" of such place (Australia ICOMOS, The Burra Charter $2013^{19}$ ). This is the aspect in repurposing projects in which most divergences arise; these projects do not only threaten the remembrance of the history of heritage sites (Aspres 2017b, 462), but also aggravate the issue of the market consumption of patrimony within the tourism industry (Choay 2011, 48).

In regards to former hospital buildings, closed because they no longer offered the necessary conditions for clinical activities, or because new hospitals were built, the requirements should be the same as the ones met in other cases of intervention on heritage buildings. In this context, taking into consideration the new developments presented in the 2005 Faro Convention-based on the endorsement of partnerships between the government and civil society-, there is a recognition of the "value" of heritage to society; an understanding of its dynamic nature,

\footnotetext{
${ }^{17}$ For further information about the project see http://www.grand-hotel-dieu.com/en/place/, https://www.patrimoine-lyon.org/la-presqu-ile/centre-ville-2/hotel-dieu and http://www.guang zhouaward.org/uploads/20191218/0d7a93c0a3b1ed376905595722bdb59b.pdf.

${ }^{18}$ See https://img.archilovers.com/projects/7ae83990-6d29-4ba7-a8bf-7446f9dbf534.pdf and https://www.dezeen.com/2018/08/21/john-pawson-transforms-historic-convent-jaffa-hotel-telaviv/.

${ }^{19}$ The Burra Charter - The Australia ICOMOS Charter for Places of Cultural Significance, 2013. Available at: https://australia.icomos.org/wp-content/uploads/The-Burra-Charter-2013Adopted-31.10.2013.pdf.
} 
resulting from a fruitful dialectic between what we inherit and what we bequeath; the adoption of heritage policies which benefit society as a whole (the concept of European common heritage); and also the prevention of possible abusive uses of patrimony, from its deterioration to potentially contentious misinterpretations. The adaptive reuse projects of historic buildings must rest on the balance between such factors, prioritising solutions with the least possible impact on the cultural significance of the places.

\section{Conclusion}

The account of the history of the Desterro building and its different inhabitants and functions over the course of the last two centuries allowed to identify distinct criteria as to how to repurpose the building and assign it a new function. Over many decades, under a laicistic and anti-religious ideology, there was an attempted erasure of the legacy of the monastery through the demolition of the church and the disfiguration of the cloister and the dormitory, executed with the aim of optimising the space for the new military or hospital functions. Such interventions gradually distanced the building from the image and idea of the monastery, which was only remembered when it came to highlight its inability to house a hospital with the adequate conditions.

As the years passed, Desterro emerged as a building which never pacifically embraced the imposed specific demands of its new role, which were detrimental to pre-existing architectural elements. At the same time, the hospital which operated in the building never had in the monastery an adequate space for its function, which sparked debate and triggered several recommendations of shutting it down over the $19^{\text {th }}$ and $20^{\text {th }}$ centuries. Its existence as a hospital is nevertheless notable in the history of medicine in Portugal, both for the medical specialties it developed and for the healthcare professionals that led them.

After the closing of the Desterro Hospital in 2007 and its consequent sale, an intervention on the former Cistercian building is projected by the architect Pedro Domingos's team. Considering the adopted guidelines based on the historical and artistic research made until that point, the project aimed to approach the building in a new way, based on the valuing of its most ancient memories while promoting a contemporary repurposing attending to present needs, interests and tendencies, aligned with rigorous economic, cultural, social and environmental sustainability criteria. It is essential that historic buildings can be integrated into urban development in order to ensure their survival. Nevertheless, it is no less crucial for remembrance not to be selective in this process. The legacy of Desterro as a hospital, in addition to the monastery vestiges, must be preserved as a mark of its own history and of the place identity (Aspres 2017a), which will have a positive impact on local residents. To protect the tangible historical heritage, although granting it new uses, it is also to respect the history of the inhabitants, involving them, directly or indirectly, in the entire transformation process.

The shutdown of key hospital units in Lisbon triggered, since the beginning, an intense public debate on the interventions planned for the group of hospital 
buildings in Colina de Santana, in which Desterro is included. In addition to essential public health issues, there was a concern about the "deep alteration of the uses and of the urban landscape" (AML 2014). The heritage and history aspects were decisive in the formulation of such arguments, contributing to the adaptive reuse project guidelines (Ashworth 2011).

As for the "compatible use", i.e., "a use which respects the cultural significance of a place", as defined in the Carta de Burra (Article 1.11), there is still some controversy. The adaptive reuse of the Desterro building in the realm of the tourism industry, while contributing to the revitalisation of a historic part of the city where social vulnerabilities abound, will nevertheless impact the area with issues such as urban touristification, tourism gentrification, and elitization (Safara and Brito-Henriques 2018).

After several advances and interruptions, the construction work is currently suspended due to the COVID-19 pandemic, leaving the city to await the new life of this monument. Meanwhile, with this study we hope to make our contribution to a broader knowledge of the building's history, while also contributing to the reflection around its conscientious future use, both in regard to cultural tourism and to urban development.

\section{Acknowledgments}

This paper was developed within the framework of the research project CuCa_RE: Cure and Care_the rehabilitation (PTDC/ATPAQI/2577/2014), funded by the Portuguese Foundation for Science and Technology (FCT).

The authors thank Architect Pedro Domingos for the permission to reproduce figures 6 to 10, and the ANTT (Arquivo Nacional da Torre do Tombo) and the Lisbon Municipal Photographic Archive for the authorisation to publish Figures 1, 2,4 and 3, 5, respectively.

The authors would also to thank to the anonymous reviewers for their helpful comments.

\section{References}

AML - Assembleia Municipal de Lisboa (2014) Debater Lisboa. Colina de Santana. Relatório Final. (Discuss Lisbon. Santana Hill. Final report). Retrieved from: http:// debaterlisboa.am-lisboa.pt/553000/1/000193,000000/index.htm. [Accessed 10 May 2020.]

Ashworth G (2011) Preservation, conservation and heritage: approaches to the past in the present through the built environment. Asian Anthropology 10(1): 1-18.

Aspres AL (2017a) Monumentos convertidos em hoteles: el sacrificio de la memoria arquitectónica. El caso de Santo Estevo de Ribas de Sil. Pasos. (Monuments turned into hotels: the sacrifice of architectural memory. Santo Estevo de Ribas de Sil). Revista de Turismo y Patrimonio Cultural 15(3): 673-685. 
Aspres AL (2017b) La reutilización hotelera del patrimonio monástico galego. (Transforming the monastic heritage of Galicia into hotels). Cuadernos de Estudios Gallegos 64(130): 431-465.

Ayers A (2019) Hospitality ward: a centuries-old Lyon hospital is converted into a fivestar hotel. Metropolis. Retrieved from: https://www.metropolismag.com/inte riors/hospitality-interiors/lyon-hotel-dieu-reuse/. [ Accessed 10 July 2020.]

Barthel-Bouchier D (2013) Cultural heritage and the challenge of sustainability. Left Coast Press: California.

Bastos C, Ramalho MM (2017) Thomaz de Mello Breyner: o hospital do Desterro e a clínica de sífilis. (Thomaz de Mello Breyner: Desterro hospital and the syphilis clinic). In AB Veloso, LD Mora, H Leitão (eds.), Médicos e Sociedade. Para uma História da Medicina no século XX, 107-126. Lisboa: By the Book.

Boudiaf B (2019) The impact of the tourism on the revitalization of the historical center. In International Conference on Protecting Cultural Heritage of the Muslim World,

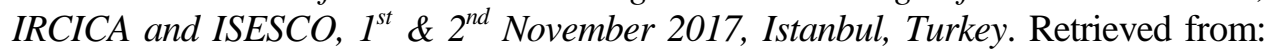
https://www.researchgate.net/publication/337146106. [Accessed 23 September 2020.]

Branco RL (2008) Italianismo e contra-reforma: a obra do arquitecto Baltazar Álvares em Lisboa. (Italianism and counter-reformation: the work of the architect Baltazar Álvares in Lisbon). Master Thesis. Lisboa: Faculdade de Ciências Sociais e Humanas - Universidade Nova de Lisboa.

Branco RL (2010) Hospital do Desterro: um mosteiro desterrado. (Desterro Hospital: an exiled monastery). Pedra \& Cal XII(46): 10-11.

Branco RL (2013) A obra filipina do Mosteiro de Na Senhora do Desterro: processo construtivo e concepção arquitectónica. (The Philippine work of the monastery of $\mathrm{N}^{\mathrm{a}}$ Senhora do Desterro: construction process and architectural design). In J Carreiras Albuquerque (ed.), Mosteiros Cistercienses. História, Arte, Espiritualidade e Património II, 107-116. Alcobaça: JOLIS.

Cabral JC (1915) O hospital real de S. José e Anexos. (The royal hospital of S. José and Annexes). Lisboa: Typ. A Editora Lda.

Choay F (2011) As questões do património: analogia para um combate. (Heritage issues: analogy for a combat). Lisboa: Edições 70.

Domingos P (2015) Antigo hospital do Desterro - Memória descritiva do projecto de alterações em obra. (The former Desterro hospital - Descriptive document of the project for work changes). Lisboa (unpublished).

Dris N (2016) Tourism and heritage: the paradoxes of a risky relationship in the Maghreb. Athens Journal of Tourism 3(4): 319-327.

Ferreira A (2014) Reutilização adaptativa do património arquitetónico. Transformação do património industrial Belga em espaços de aprendizagem. (Adaptive reuse of architectural heritage. Transformation of the Belgian industrial heritage into learning spaces). Master Thesis. Lisboa: IST-Técnico Lisboa.

Flanagan K (2018) 6 former asylums restored as beautiful, spacious hotels. Architectural Digest. Retrieved from: https://www.architecturaldigest.com/story/fo rmer-asylumhotels. [Accessed 10 July 2020.]

Gholitabar S, Costa C (2018) Adaptive reuse in cultural heritage building. Revista Turismo \& Desenvolvimento 30(2018): 73-91.

Gholitabar S, Alipour H, Costa CMM (2018) An empirical investigation of architectural heritage management implications for tourism: the case of Portugal. Sustainability 10(1): $1-32$. 
Hall MC, Baird T, James M, Ram Y (2016) Climate change and cultural heritage: conservation and heritage tourism in the Anthropocene. Journal of Heritage Tourism 11(1): 10-24.

Ismagilova G, Safiulli, L, Gafuov I (2015) Using historical heritage as a factor in tourism development. Procedia - Social and Behavioral Sciences 188(2015): 157-162.

Langston C, Wong FK, Hui ECM, Shen LY (2008) Strategic assessment of building adaptive reuse opportunities in Hong Kong. Building and Environment 43(10): $1709-1718$.

Lima MC (2014) Conceitos e atitudes de intervenção arquitetónica em Portugal, 17551834. (Concepts and attitudes for architectural intervention in Portugal, 1755-1834). Doctoral Thesis. Lisboa: Faculdade de Letras - Universidade de Lisboa.

Matos JS, Branco RL (2014) Estudo Histórico-Patrimonial do antigo mosteiro cisterciense de $N^{a}{ }^{a}$ Senhora do Desterro - Orientações para a reintegração arquitectónica do imóvel. (Historical and heritage study of the former Cistercian monastery of $\mathrm{N}^{\mathrm{a}}{ }^{\mathrm{a}}$ Senhora do Desterro - Guidelines for its architectural reintegration). Lisboa (unpublished).

Mora LD (2011) Desterro: vida e morte de um hospital. (Desterro: life and death of a hospital). In Clínica, Arte e Sociedade. A sífilis no Hospital do Desterro e na saúde pública. Lisboa: Imprensa de Ciências Sociais, 41-56.

Mowforth M, Munt I (1998) Tourism and sustainability: new tourism in the third World. London: Routledge.

Nasser N (2003) Planning for urban heritage places: reconciling conservation, tourism, and sustainable development. Journal of Planning Literature 17(4): 467-479.

Nilsson PA (2018) Impact of cultural heritage on tourists. The heritagization process. Athens Journal of Tourism 5(1): 35-54.

Palmer M, Nevell M, Sissons M (2012) Industrial archaeology: a handbook. York: Council for British Archaeology.

Papanikos GT (2020) The impact of the Covid-19 pandemic on Greek tourism. Athens Journal of Tourism 7(2): 87-100.

Pascoal AM, Neto MJ, Soares CM (2020) From hospital to hotel - urban heritage, adaptive reuse and sustainable tourism: the case of the S. Marcos hospital in Braga, Portugal. Journal of Research and Didactics in Geography 1(Jun): 167-181.

Pilão C, Tacão S (2013) Lisboa, Colina de Sant'Ana: monges, monárquicos e republicanos, 500 anos a tratar da saúde do povo. (Lisbon, Colina de Sant'Ana: monks, monarchists and republicans, 500 years dealing with the health of the people). Amazônica. Revista de Antropologia 5(2): 288-306.

Pincha JP (2018) Nova vida do hospital do Desterro talvez comece em meados de 2019. (New life at Desterro hospital may begin in mid-2019). Público.

Powter A, Ross S (2005) Integrating environmental and cultural sustainability for heritage properties. APT Bulletin 36(4): 5-11.

Projeto Lx Conventos - Mosteiro de Nossa Senhora do Desterro. (Lx Convents ProjectMonastery of Nossa Senhora do Desterro). Retrieved from: http://patrimoniocultural. cm-lisboa.pt/lxconventos/ficha.aspx?t=i\&id=580. [Accessed 28 June 2020.]

Rypkema D, Cheong C (2011) Measurements and indicators of heritage as development. In ICOMOS $17^{\text {th }}$ General Assembly, 2011-11-27/2011-12-02, Paris, France. Retrieved from: http://openarchive.icomos.org/id/eprint/1283. [Accessed 25 May 2020.]

Safara J, Brito-Henriques E (2018) O hotel Santiago de Alfama como alegoria da política recente de regeneração urbana. (The Santiago de Alfama Hotel as an allegory of the recent urban regeneration policy). Finisterra LII(106): 65-84. 
Soares M (2013) Vai ser possível cultivar hortas ou trabalhar num quarto do antigo hospital do Desterro. (It will be possible to grow gardens or work in a room of the former Desterro hospital). Público.

Soares M (2014) Reabilitação do antigo hospital do Desterro está parada e sem data para avançar. (Rehabilitation of the former Desterro hospital is stopped and has no date to advance). Público.

Sousa IF de (2013) Intervir no património. Reconversão do hospital do Desterro em unidade hoteleira. (Intervene in heritage. Conversion of Desterro hospital into a hotel). Master Thesis. Lisboa: Universidade Técnica de Lisboa, Faculdade de Arquitetura.

Tomás C (2015) A futura vida do Desterro. (Desterro's future life). Expresso. 
